\title{
Transfer of Protein from Milk to Cheese ${ }^{1}$
}

\author{
D. B. Emmons ${ }^{2}$, C. Dubé ${ }^{3}$, and H. W. Modler ${ }^{4}$ \\ Food Research Program, \\ Research Branch, Agriculture and Agri-Food Canada, \\ 93 Stone Road, Guelph, Ontario, N1G 5C9
}

\section{ABSTRACT}

This report concerns measurement of paracasein in milk and transfer of protein from milk to cheese. In the main experiment, two vats of Cheddar cheese were made from each of 11 lots of milk from one large herd over a period of $7 \mathrm{mo}$.

Exclusion of solutes from moisture in paracasein micelles in milk and cheese was central to estimation of paracasein and to the transfer of protein from milk to cheese and whey. Solute-exclusion by paracasein and its changes during cheesemaking could be visualized by considering paracasein micelles to be a very fine sponge. The sponge excludes solutes, especially the large solutes like whey proteins. The sponge shrinks during cheesemaking and expels solute-free liquid, thereby slightly diluting the whey surrounding the micelles inside the curd.

Paracasein $\mathrm{N}$ in milk was calculated as the difference between total milk $\mathrm{N}$ and rennet whey $\mathrm{N}$, the latter adjusted to its level in milk. Adjustment used appropriate solute-exclusion factors $(h)$ of the protein fractions of whey and 1.08 for paracasein and associated salts. They were combined to give a factor Fpc, which adjusted the level of rennet whey $\mathrm{N}$ to its level in milk: $1.001 \times(1-1.01 \times \mathrm{FM} / 100-\mathrm{Fpc} \times \mathrm{pc} / 100)$, where $\mathrm{FM}=$ fat in milk, $\mathrm{pc}=$ estimated paracasein, and $1.001=$ dilution of milk by chymosin and $\mathrm{CaCl}_{2}$. The mean Fpc was 3.03. Differences in values were small among different procedures for calculating paracasein, but they are considered to be important because they represent biases, which, in turn, are important in analyses commercially.

Received April 16, 2002.

Accepted July 27, 2002.

Corresponding author: D. B. Emmons; e-mail: dbemmons@ iglide.net.

${ }^{1} \mathrm{~A}$ publication from the Food Research Program (Guelph), Research Branch, Agriculture and Agri-Food Canada.

${ }^{2}$ Current address: 657 Westminster Ave., Ottawa, ON, K2A 2V7, Canada.

${ }^{3}$ Current address: Centre de recherche et de développement sur les aliments, 3600 Casavant Blvd. Ouest, St. Hyacinthe, QC, J2S 8E3, Canada.

${ }^{4}$ Current address: 1253 River Rd., Kemptville, ON, K0G 1J0, Canada.
We conclude that solute exclusion by moisture in paracasein must have decreased during cheesemaking because the ratio of moisture to paracasein in the final cheese was 1.5, much less than the $h$ of 2.6 for serum proteins by paracasein. Release of solute-excluding moisture from paracasein during cooking was likely the reason for lower total $\mathrm{N}$ in cheese whey than in the rennet whey in the paracasein analysis.

Paracasein, estimated to be in cheese, curd fines, salted whey, and whey during cheddaring, was 98.21 , $0.20,0.25$ and $0.19 \%$, respectively, of the paracasein in milk for a total of $98.85 \%$ (SD of 22 vats $=0.46$ ); the location of the missing paracasein is not known. On the other hand, recovery of milk $\mathrm{N}$ in cheese and wheys was $99.92 \%$ ( $\mathrm{SD}=0.37 \%$ ). Nitrogen in paracasein and its hydrolysis products in cheese was estimated to be $98.51 \%$ of total cheese $\mathrm{N}$.

Proteose-peptone from milk appeared not to be included with the paracasein in appreciable amounts. Some was apparently included with denatured serum proteins during Rowland fractionation of whey, perhaps as a coprecipitate. Measured paracasein would include fat globule membrane proteins in milk containing fat, and denatured whey proteins in heated milks. It was concluded that the method of measurement and the associated calculations are integral parts of the definition and quantification of paracasein in milk.

(Key words: Paracasein, milk, cheese, analysis)

Abbreviation key: CMK = milks from cheese plants, Fcas and Fpc $=$ factors including $h$, protein, and associated salts, in adjusting levels of $\mathrm{N}$ in estimating casein and paracasein, respectively, $\boldsymbol{h}=$ solute-exclusion factor, $\mathbf{H M K}=$ milks from one herd, IMK = milks from individual cows, $\mathbf{P P}=$ proteose-peptone, $\mathbf{S P}=$ serum proteins.

\section{INTRODUCTION}

The transfer of protein from milk to cheese has been of interest for more than a century. The casein of milk was recognized as a prime determinant of cheese yield, resulting in formulas for predicting yield of cheese, based on the fat and casein content of the milk (Bab- 
cock, 1895; Van Slyke and Publow, 1910; Van Slyke and Price, 1949). The formula of Van Slyke and Publow (1910) allowed for the loss of casein in the factor "Casein $-0.1 "$.

Much work has been published in the intervening years on the transfer of the casein in milk to cheese, in particular, the splitting of the caseomacropeptide (CMP) from $\kappa$-CN. This transfer has been reviewed by van Boekel (1994) and van den Berg et al. (1996); the conclusion is that measurement of paracasein in casein or in milk may be a more accurate predictor of cheese yield than casein. The proportion of paracasein in casein may vary due to differing genetic variants; for example, the B-variant of $\kappa$-CN is associated with higher proportions of that protein in casein (van den Berg et al., 1992). Evidence was presented by van Boekel and Crijns (1994) that most of the proteosepeptone (PP) fraction of milk was retained in the paracasein coagulum, although this is questioned by data in our study. Approximately two-thirds of the PP fraction of milk appeared to be included in whole-milk ricotta cheese (Modler and Emmons, 1989a; 1989b). This cheese was made by heating and direct acidification and no rennet was used.

Lolkema (1994) described the use of protein in milk and cheese whey measured using dye-binding analysis in commercial practice in Friesland, the Netherlands; in essence, paracasein was measured. Posthumus et al. (1964) estimated paracasein by multiplying the protein in milk by the proportion of casein in total protein and again by the proportion of paracasein in casein (ca. 0.96). This formula was further modified to include the calcium and phosphate associated with the casein micelle. In practice, these three factors were combined into a single factor, $\alpha$; this factor was modified seasonally, and used in a formula for predicting cheese yield.

Karman et al. (1987), van Boekel (1994), and van den Berg et al. (1996) determined paracasein $\mathrm{N}$ in milk by measuring infrared absorption in milk and whey by spectroscopy; from this, casein was estimated (Karman et al., 1987). van den Berg et al. (1996) advocated the measurement of paracasein and its use in the control of cheesemaking; for example, they standardized milk to a constant paracasein/fat ratio and added constant amounts of paracasein to a vat rather than constant volumes of milk.

The estimation of paracasein is not simple. Absorption of infrared light by protein in whey is different from that in milk and requires a special calculation (Karman et al., 1987), or separate calibrations for protein in milk and in whey. Paracasein $\mathrm{N}$ is estimated as the difference between total $\mathrm{N}$ and nonparacasein $\mathrm{N}$ in milk. The calculation of the latter (see below) is complex, because of a phenomenon known as solute exclusion.

Solute or steric exclusion by casein and paracasein (Walstra and Jenness, 1984; van Boekel and Walstra, 1989 ) is an important concept in formulas for estimation of paracasein and in understanding the transfer of protein from milk to cheese. Casein in milk and paracasein in rennet coagulum have water in them or associated with them that excludes solutes, excluding more for large molecules like whey proteins and less for smaller molecules like those in NPN. The soluteexclusion factor $(\boldsymbol{h})$ for a solute by casein is the proportion of the mass of the water excluding that solute to the mass of casein. For example, the $h$ values for casein and paracasein used here are 0.2 for NPN, 1.5 for CMP and 2.6 for PP and serum proteins (SP) (van Boekel and Walstra, 1989; van den Berg et al., 1996); the mass of water that excludes PP and SP is 2.6 times the mass of the paracasein.

This report is part of a larger study on cheese yield and focuses on the quantitative transfer of protein in milk to cheese, namely that of paracasein. It evaluates various methods of calculation of paracasein and attempts to quantitate the transfer of paracasein to cheese and whey. This report also assesses changes in solute exclusion by paracasein during cheesemaking, and whether PP is retained in the rennet coagulum.

\section{MATERIALS AND METHODS}

\section{Sources of Milk}

Eleven lots of milk were obtained from the milking herd of 130-150 Holstein-type cows at the Greenbelt Farm of the Centre for Food and Animal Research from May to November. These were denoted herd milks (HMK).

Data are presented from another study in which milk was collected monthly, from September to November, from 10 cheese plants across Canada. At each collection time, representative portions of all the raw milk received during a 48-h period were frozen and shipped by courier to Ottawa. They were then thawed quickly in a microwave oven, mixed and sampled for analysis. There were 29 samples, denoted cheese plant milks (CMK). Data presented by van Boekel and Crijns (1994) were used for comparison and illustration and were denoted individual cow milks (IMK), although three of the 11 samples were commercial bulked milks.

\section{Cheesemaking}

Two vats containing $210-215 \mathrm{~kg}$ of weighed heattreated milk $\left(60^{\circ} \mathrm{C}, 30 \mathrm{~min}\right)$ were made conventionally 
into Cheddar cheese from each lot of HMK milk. The temperature, lower than pasteurization, was selected to minimize denaturation of serum proteins. Frozen starter concentrate (DVS, No. 604, courtesy of HoranLally Inc., Division of Chr. Hansen's Lab, Inc., Waukesha, WI) was used. Each vat was ripened for $60 \mathrm{~min}$ at $31^{\circ} \mathrm{C}$ before adding $24 \mathrm{ml}$ of double-strength rennet (microbially derived chymosin, CHYMAX, courtesy of Chas. Pfizer, Inc., Milwaukee, WI) diluted to $250 \mathrm{ml}$ with tap water. Thirty-four $\mathrm{ml}$ of lactic acid (85\%) was added to one vat. Cooking temperature was $39^{\circ} \mathrm{C}$. Weighed whey from each vat was collected in a vertical covered vat until the end of cheddaring, then blended and sampled. For each vat, cheese in two rectangular hoops was placed in a plastic bag and pressed overnight; the expressed whey in the bag was weighed, heated to $50^{\circ} \mathrm{C}$, poured into a $15-\mathrm{L}$ can, blended with an in-can homogenizer (Ultra Turrax, Type T65DPX S15, Janke \& Kunkel GMBH \& Co. KG, Staufen, Germany), and sampled. Cheese was placed in plastic bags, vacuum-sealed (Multivac A-300-32, Sepp Haggenmuller KG, Wolfertschwenden, Germany), held at $15^{\circ} \mathrm{C}$ for five days, sampled, and blended (Model DLC 10 Classic, Cuisinart Corp., East Windsor, NJ). One 500- to 700-g sample of cheese was taken from each end of each of the two blocks (Figure 1) from each vat; one sample comprised two wedges of cheese (Figure 1); the four samples were analyzed separately.

Milk, whey, and cheese were weighed on a platform scale (32-kg capacity, 0.1- and 1-g divisions, Model PE6, Mettler Instruments, Zurich, Switzerland); milk and whey were weighed in $36.4-\mathrm{Kg}$ milk cans by difference, both before and after emptying.

\section{Curd Fines}

The procedure of van den Berg et al. (1973) was modified slightly as follows. A 1-L sample of blended whey was again blended, by stirring, and each of three 250-ml portions were divided among six $50-\mathrm{ml}$ centrifuge tubes; these were centrifuged for $12 \mathrm{~min}$ at $3300 \times$ g (Model 1000, Mistral, Sanyo Canada Inc., Industrial Products Div., Concord, ON, Canada). Whey was poured off for $\mathrm{N}$ analysis; liquid fat was also removed from the side of the tube with a tissue, an essential step. Pellets were collected in one tube with distilled water, recentrifuged, and collected with suction on preweighed filter paper (Whatman No. 40) on a Buchner funnel, rinsed again with warm distilled water, dried overnight at $100^{\circ} \mathrm{C}$ in a forced-draft oven, cooled and reweighed. The entire paper was digested for $\mathrm{N}$ analysis. Data were collected for both weight and N, but only $\mathrm{N}$ is reported here. Filter paper was essential for $\mathrm{N}$ analysis, rather than glass-based filters because the

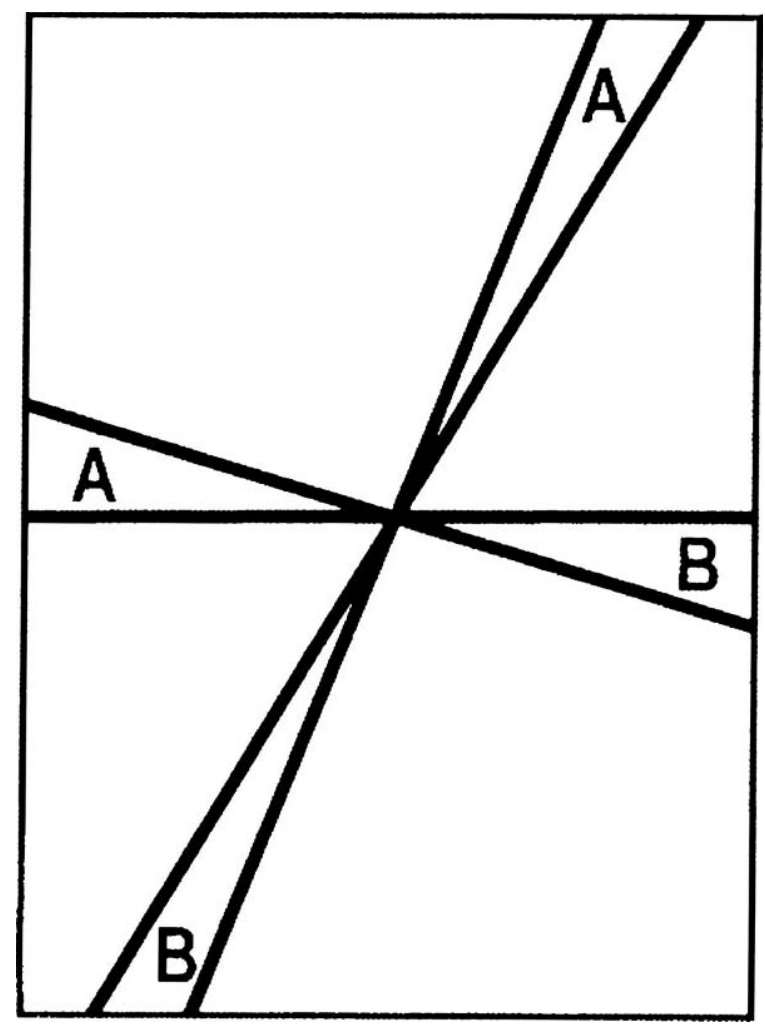

Figure 1. Pattern of taking two samples, A and B, from each of two blocks of cheese from each vat for analysis. This was a pragmatic modification of the IDF procedure 50B (1985) for sampling a large rectangular block.

latter interfered with digestion. Paper absorbed moisture from the air, so a special procedure was used; filter papers were separated by sheets of $\mathrm{Al}$ foil in the desiccator and weighed in that order, before and after drying; one blank filter paper was between each sample trio. The weight of the dried curd or the $\mathrm{N}$ in the $250-\mathrm{ml}$ sample multiplied by 4 is the curd fines content of the whey, expressed as $\mathrm{g} / \mathrm{L}$ of whey; these data were further adjusted to $\mathrm{g} / 100 \mathrm{~g}$ of milk using a density of 1.025 for whey and using the weights of whey and milk in the vat.

\section{Preparation of Rennet Whey}

The method of Karman et al. (1987) was slightly modified. One drop each of double-strength rennet (Pfizer) and $20 \%$ (w/v) $\mathrm{CaCl}_{2}$ solution was added to 50 $\mathrm{ml}$ of milk at $30^{\circ} \mathrm{C}$. It was allowed to coagulate for 30 min and centrifuged (Mistral 1000) at $4750 \times g$ for 20 min, then filtered through Whatman No. 40 filter paper. The results were corrected by multiplying by 1.001 to account for dilution. 


\section{Fractionation}

Milk and whey were fractionated into casein (IDF, 1964a), SP, PP, and NPN by the Rowland procedure (Rowland, 1938). Noncasein $\mathrm{N}$ in milk was estimated by fractionation at $40^{\circ} \mathrm{C}$; flasks were weighed before and after adding milk, and again after adding acid and water. A four-decimal balance was used for weighing milk or whey. For estimation of PP and SP, weighed amounts of milk or whey (ca. $10 \mathrm{~g}$ ) in a stoppered testtube were heated in a boiling water bath $\left(>97^{\circ} \mathrm{C}\right)$ for 20 min, ensuring that the water level was higher than that of the milk. The heated milk was quantitatively transferred to previously weighed volumetric flasks for acid precipitation. The NPN was determined by weighing $20 \mathrm{~g}$ of milk or whey into a previously weighed $100-\mathrm{ml}$ volumetric flask, followed by reweighing the full flask after addition of the TCA solution $(150 \mathrm{~g} / \mathrm{L})$. Weighed portions of the filtrates were added to the Kjeldahl digestion flasks.

\section{Analysis}

Nitrogen was determined by the IDF Kjeldahl procedure (IDF, 1986b) with $\mathrm{CuSO}_{4}$ using $5 \mathrm{~g}$ of milk or whey, $0.6-0.8 \mathrm{~g}$ of cheese, $25 \mathrm{~g}$ of noncasein $\mathrm{N}$ filtrate for casein (IDF, 1964a) or PP filtrate and $30 \mathrm{~g}$ of TCA filtrate (Kjeldatherm Digestion System and Vapodest6 Distillation System, Gerhardt, Bonn, Germany). Weighed samples of $\left(\mathrm{NH}_{4}\right)_{2} \mathrm{SO}_{4}$ solution, containing approximately the same amount of $\mathrm{N}$ as the sample, preceded a series of tubes containing samples with the larger amounts of $\mathrm{N}$ (milk and cheese) to overcome a tendency for carry-over of $\mathrm{N}$ between tubes. Blanks at the end always contained small amounts of $\mathrm{N}$ and the first tube in a series tended to be lower than those following unless the system was first flooded with $\mathrm{N}$. Blanks were determined before the beginning of a series. Conversion factors for $\mathrm{N}$ to protein were 6.31 for paracasein, 6.36 for casein, or 6.38 for all $\mathrm{N}$; the 6.31 and 6.36 were calculated as appropriate conversion factors from amino acid compositions of those protein fractions by van Boekel and Ribideau-Dumas (1987).

Fat was determined by IDF methods, (IDF, 1983) for milk and whey using $\mathrm{NH}_{4} \mathrm{OH}$, and (IDF, 1986a) for cheese using $\mathrm{HNO}_{3}$. Evaporating dishes for acid extracts from cheese were glass because an apparent carry-over of acid caused corrosion of aluminum dishes and variable high blanks; observed values for fat in cheese using aluminum dishes were close to those using glass, but more variable.

The number of replicates was relatively high for some analyses in the HMK experiment: three replicates on each of four subsamples per vat for fat, protein and noncasein $\mathrm{N}$ at $40^{\circ} \mathrm{C}$ and for casein in milk and moisture in cheese; duplicate analyses on each of four subsamples for fat, protein, and salt for cheese, for a total of 12 or 8 analyses per vat; all others were triplicate analyses on one sample, except duplicate analyses for fractions of rennet and cheese wheys. The relatively high number of some replicate analyses was partly to assure the highest possible accuracy, and partly for use in a subsequent study on the effect of replicate analysis on LSD of yield experiments. In the CMK experiment, there were two analyses on each of two subsamples for $\mathrm{N}$ and fat.

\section{Solute-Exclusion}

Solute-exclusion factors were used to estimate the levels of protein fractions in milk from analyses of the rennet whey and of filtrates of acid precipitation: 0.2 for NPN of milk (van Boekel and Crijns, 1994), 1.5 for CMP (van den Berg et al., 1996); and 2.6 for PP and SP (van Boekel and Walstra, 1989). The level in milk of a protein fraction in whey was estimated by multiplying the level in whey by:

$$
(1-1.01 f-1.08 p-h p), \quad \text { Adjustment [1] }
$$

where $f$ is the fraction of fat in milk (e.g., 4/100), $p$ is the fraction of paracasein in milk, and $h$ is the soluteexclusion factor (Walstra and Jenness, 1984); the 1.08 includes the weight of casein-associated salts (Walstra and Jenness, 1984). Adjustment of protein levels in acid filtrates used 1.00 instead of 1.08 , and $f$ and $p$ were divided by 1000 instead of 100 .

\section{RESULTS}

\section{Composition}

Milks and rennet wheys were fractionated and analyzed for $\mathrm{N}$ in two experiments, HMK (milks from one herd) and CMK (milks from cheese plants). The data were used for calculating levels of $\mathrm{N}$ fractions in milk, including paracasein, and in whey. Also, data published by van Boekel and Crijns (1994) on composition of skim milk were used for similar calculations, called experiment IMK (individual cows). Data from the HMK experiment were also used to evaluate the transfer of paracasein from milk to cheese and wheys.

Table 1 shows the proteinaceous compositions of milks, wheys, curd fines, and cheese, and of certain filtrates derived from milks and unsalted wheys of the HMK data. Filtrates were actual levels, before adjustment for estimating the level of a component in milk or whey. Mean levels of fat and protein were 3.67 and $3.09 \%$, respectively. These are somewhat lower than generally found in Canadian milk, e.g. the 3.77 
Table 1. Proteinaceous $(\mathrm{N} \times 6.38)$ composition of milk, wheys, and cheese in 22 vats of cheese made from 11 lots of milk from one herd.

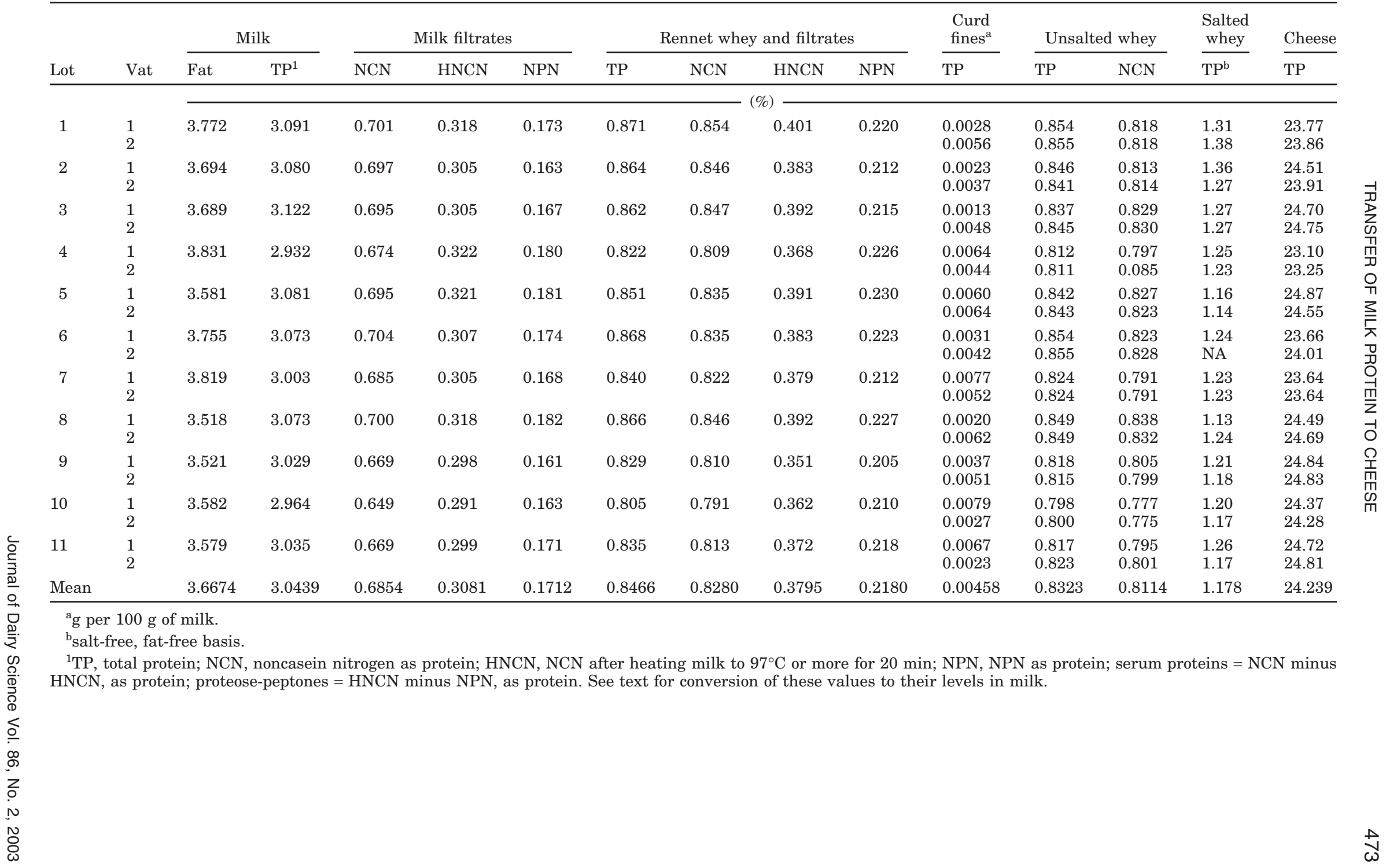


Table 2. Mean levels of protein fractions $(\mathrm{N} \times 6.38)$ and fat in milks from one herd (HMK), skim milks from individual cows (IMK) (Van Boekel and Crijns, 1994), and cheese plant milks (CMK).

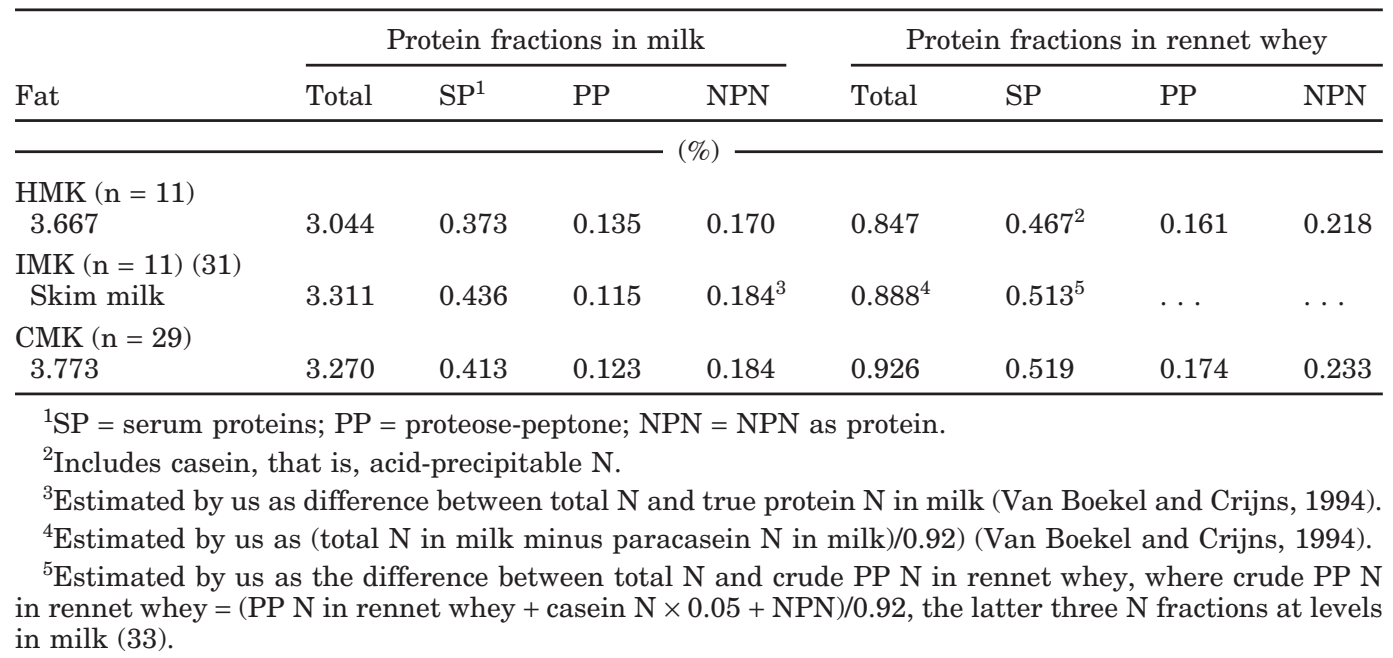

and $3.27 \%$, respectively, in the commercial milk in the CMK experiment in Table 2.

Table 2 shows means of $\mathrm{N}$ contents of fractions from the three experiments: HMK, IMK and CMK. The IMK data also contain estimates of fractions calculated from published fractions (van Boekel and Crijns, 1994). The mean levels in milk of total proteins, SP and NPN were higher in the IMK and CMK experiments than in the HMK experiment, whereas the PP was slightly higher in the last.

\section{Recovery of Nitrogen from Milk in Cheese, Curd Fines and Wheys}

Table 3 shows the percentage recoveries of $\mathrm{N}$ from milk in cheese, curd fines and unsalted and salted wheys in the HMK milks. The mean was $99.92 \%$ with a standard deviation of $0.37 \%$ among the 22 vats, indicating uniform recovery. The reduction of the standard deviation of $0.50 \%$ for recovery in cheese to $0.37 \%$ for total recovery was apparently due to balancing recoveries in other $\mathrm{N}$ fractions. The differences in recoveries of $\mathrm{N}$ among the 11 trials were significant $(P<0.01)$; the cause is not known. Almost all of the deviations in total recovery were reflected in deviations in one of the fractions; for example, high total recovery in trials 5 and 11 were coincident with recoveries as cheese that were higher than the mean.

\section{Estimation of Paracasein in Milk}

The paracasein content of milk was estimated by a modification of the procedure described by Karman et al. (1987), van Boekel (1994), van Boekel and Crijns (1994), and van den Berg et al. (1996). Solute-exclusion factors by paracasein were 0.2 for NPN, 1.5 for CMP $\mathrm{N}$ and 2.6 for SP N and PP N. The modification was that levels of paracasein were calculated individually for each milk using these factors, as follows. Levels, each of NPN, CMP N, and SP + PPN, were adjusted to their levels in milk by multiplying by

$$
\begin{aligned}
& {[1-1.01 \times \mathrm{FM} / 100-(h+1.08) \times \mathrm{PM}} \\
& \quad \times 0.7463 / 100] \times 1.001 \quad \text { Adjustment }[2]
\end{aligned}
$$

Using the appropriate $h$, where FM and PM were percentages of fat and protein in milk, respectively; 1.001 accounts for dilution by chymosin and $\mathrm{CaCl}_{2}$ solutions during rennet whey preparation. The level of paracasein in milk was then the difference between milk total $\mathrm{N}$ and the sum of the other $\mathrm{N}$ components at their levels in milk. The conversion factor of 0.7463 for protein in milk to paracasein was the mean value in the HMK experiment. A difference of 0.001 in the conversion factor would make a difference of $0.0008 \%$ of paracasein, that is, from 2.5 to 2.5008 . This difference was considered to be small and this conversion factor was used throughout.

The above exercise was started initially because the total protein levels in the HMK were somewhat lower than those in the previous study (van Boekel and Crijns, 1994) which used 0.92 to convert $\mathrm{N}$ levels in rennet whey to those in skim milk. The latter gave estimates of paracasein that were $0.009 \%$ higher than those using the described calculations. A similar situation existed using the F3 values of van Boekel (1994); $\mathrm{F} 3$ was another factor for converting the level of $\mathrm{N}$ in rennet whey to its level in milk containing fat.

The above method for calculation of paracasein $\mathrm{N}$ with Procedure 2 could be reduced to one calculation, 
Table 3. Transfer of $\mathrm{N}$ from milk to cheese, curd fines, unsalted whey, and salted whey, expressed as percentages of $\mathrm{N}$ in milk in the HMK experiment using milk from one herd.

\begin{tabular}{|c|c|c|c|c|c|c|}
\hline Trial & Vat & Cheese & $\begin{array}{l}\text { Curd } \\
\text { fines }\end{array}$ & $\begin{array}{l}\text { Unsalted } \\
\text { whey }\end{array}$ & $\begin{array}{l}\text { Salted } \\
\text { whey }\end{array}$ & Total \\
\hline & & & & $-(\%)$ & & 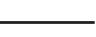 \\
\hline 1 & $\begin{array}{l}1 \\
2\end{array}$ & $\begin{array}{l}74.64 \\
74.68\end{array}$ & $\begin{array}{l}0.09 \\
0.18\end{array}$ & $\begin{array}{l}24.41 \\
24.59\end{array}$ & $\begin{array}{l}0.59 \\
0.59\end{array}$ & $\begin{array}{r}99.74 \\
100.04\end{array}$ \\
\hline 2 & $\begin{array}{l}1 \\
2\end{array}$ & $\begin{array}{l}74.76 \\
74.94\end{array}$ & $\begin{array}{l}0.08 \\
0.12\end{array}$ & $\begin{array}{l}24.41 \\
24.26\end{array}$ & $\begin{array}{l}0.61 \\
0.54\end{array}$ & $\begin{array}{l}99.86 \\
99.86\end{array}$ \\
\hline 3 & $\begin{array}{l}1 \\
2\end{array}$ & $\begin{array}{l}75.12 \\
75.10\end{array}$ & $\begin{array}{l}0.04 \\
0.16\end{array}$ & $\begin{array}{l}23.68 \\
24.15\end{array}$ & $\begin{array}{l}0.56 \\
0.53\end{array}$ & $\begin{array}{l}99.40 \\
99.94\end{array}$ \\
\hline 4 & $\begin{array}{l}1 \\
2\end{array}$ & $\begin{array}{l}74.69 \\
74.76\end{array}$ & $\begin{array}{l}0.22 \\
0.15\end{array}$ & $\begin{array}{l}24.72 \\
24.67\end{array}$ & $\begin{array}{l}0.66 \\
0.59\end{array}$ & $\begin{array}{l}100.29 \\
100.17\end{array}$ \\
\hline 5 & $\begin{array}{l}1 \\
2\end{array}$ & $\begin{array}{l}75.50 \\
75.30\end{array}$ & $\begin{array}{l}0.20 \\
0.21\end{array}$ & $\begin{array}{l}24.49 \\
24.48\end{array}$ & $\begin{array}{l}0.46 \\
0.44\end{array}$ & $\begin{array}{l}100.64 \\
100.43\end{array}$ \\
\hline 6 & $\begin{array}{l}1 \\
2\end{array}$ & $\begin{array}{l}74.33 \\
74.22\end{array}$ & $\begin{array}{l}0.10 \\
0.14\end{array}$ & $\begin{array}{l}24.48 \\
24.36\end{array}$ & $\begin{array}{l}0.87 \\
1.03\end{array}$ & $\begin{array}{l}99.78 \\
99.77\end{array}$ \\
\hline 7 & $\begin{array}{l}1 \\
2\end{array}$ & $\begin{array}{l}73.84 \\
73.92\end{array}$ & $\begin{array}{l}0.26 \\
0.17\end{array}$ & $\begin{array}{l}24.53 \\
24.50\end{array}$ & $\begin{array}{l}0.60 \\
0.57\end{array}$ & $\begin{array}{l}99.23 \\
99.16\end{array}$ \\
\hline 8 & $\begin{array}{l}1 \\
2\end{array}$ & $\begin{array}{l}74.75 \\
74.66\end{array}$ & $\begin{array}{l}0.06 \\
0.20\end{array}$ & $\begin{array}{l}24.49 \\
24.62\end{array}$ & $\begin{array}{l}0.51 \\
0.50\end{array}$ & $\begin{array}{l}99.81 \\
99.98\end{array}$ \\
\hline 9 & $\begin{array}{l}1 \\
2\end{array}$ & $\begin{array}{l}75.24 \\
75.27\end{array}$ & $\begin{array}{l}0.12 \\
0.17\end{array}$ & $\begin{array}{l}24.13 \\
24.05\end{array}$ & $\begin{array}{l}0.48 \\
0.49\end{array}$ & $\begin{array}{l}99.96 \\
99.98\end{array}$ \\
\hline 10 & $\begin{array}{l}1 \\
2\end{array}$ & $\begin{array}{l}75.00 \\
75.19\end{array}$ & $\begin{array}{l}0.27 \\
0.09\end{array}$ & $\begin{array}{l}24.02 \\
24.00\end{array}$ & $\begin{array}{l}0.49 \\
0.46\end{array}$ & $\begin{array}{l}99.77 \\
99.74\end{array}$ \\
\hline 11 & $\begin{array}{l}1 \\
2\end{array}$ & $\begin{array}{l}75.68 \\
75.69\end{array}$ & $\begin{array}{l}0.22 \\
0.08\end{array}$ & $\begin{array}{l}24.07 \\
24.17\end{array}$ & $\begin{array}{l}0.39 \\
0.39\end{array}$ & $\begin{array}{l}100.36 \\
100.33\end{array}$ \\
\hline $\begin{array}{c}\text { Mean } \\
\text { SD }\end{array}$ & & $\begin{array}{r}74.88 \\
0.50\end{array}$ & $\begin{array}{l}0.15 \\
0.06\end{array}$ & $\begin{array}{r}24.33 \\
0.26\end{array}$ & $\begin{array}{l}0.56 \\
0.15\end{array}$ & $\begin{array}{r}99.92 \\
0.37\end{array}$ \\
\hline
\end{tabular}

as the difference between the total $\mathrm{N}$ in milk and the levels of rennet whey total N (RWTN) adjusted to their levels in milk by

$$
\begin{aligned}
\mathrm{RWTN} & \times(1-1.01 \times \mathrm{FM} / 100-\mathrm{Fpc} \times \mathrm{PM} \\
& \times 0.7463 / 100) \times 1.001 \quad \text { Adjustment }[3]
\end{aligned}
$$

where Fpc $=$ the pooled $h+1.08$ for paracasein. This resulted in Fpc values of 3.04, 3.03, and 3.03 for the HMK, IMK and CMK experiments, respectively (Table 4). Ranges of Fpc among milks within experiments were from 0.08 to 0.18 .

The magnitude of Fpc depends on the ratios of the relative amounts of the components or fractions of $\mathrm{NPN}, \mathrm{SP}+\mathrm{PP}$, and CMP in the whey. There was no apparent relationship between the level of protein in the milks and the magnitude of Fpc. It was not possible to know from the data how much of the variation was due to analytical variation or to biological variation. The closeness of the means of the three experiments suggest that the major part of the variation was analytical. The use of 2.9 instead of 3.03 made a difference of $0.003 \%$ in estimated paracasein. The ranges of Fpc in Table 4 were judged not to be important as long as the difference was not a bias, suggesting that factors of 3.00 for Fcas and Fpc could be used elsewhere. We conclude that adjustment [3] can be used for converting $\mathrm{N}$ in rennet whey to levels in milk for estimation of paracasein $\mathrm{N}$ in milks with relatively wide ranges in composition.

Table 5 shows mean levels of paracasein in the milks of the three experiments, estimated by different procedures using a $\mathrm{N}$ conversion factor of 6.31 . The procedure, in the column under Appropriate Fpc, was considered the reference because it was based on analyses of component fractions in each individual milk and its whey. The extrapolated values of F3 of van Boekel

Table 4. Means of factor Fpc combining solute-exclusion factors of all the whey protein fractions, as well as the 1.08 for paracasein and its salts for estimation of paracasein $\mathrm{N}$ in milk.

\begin{tabular}{lll}
\hline & \multicolumn{2}{c}{$\mathrm{Fpc}^{1}$} \\
\cline { 2 - 3 } Experiment & Mean & Range \\
\hline $\begin{array}{l}\text { Herd milks } \\
(\mathrm{n}=11)\end{array}$ & 3.04 & 0.08 \\
$\begin{array}{l}\text { Individual cow } \\
\text { milks }(\mathrm{n}=11)\end{array}$ & 3.03 & 0.18 \\
$\begin{array}{l}\text { Commercial milks } \\
(\mathrm{n}=29)\end{array}$ & 3.03 & 0.08 \\
\hline
\end{tabular}

\footnotetext{
${ }^{1} \mathrm{Fpc}-$ in $(1-\mathrm{FM} \times 1.01 / 100-\mathrm{Fpc} \times \mathrm{pcM} / 100)$ for estimating paracasein in milk, where $\mathrm{FM}=$ fat in milk, and pcM = paracasein in milk.
} 
Table 5. Means of estimates of paracasein, as the difference between total milk $\mathrm{N}$ and different methods of adjustment of levels of $\mathrm{N}$ in rennet whey to their levels in milk.

\begin{tabular}{|c|c|c|c|c|c|}
\hline \multirow[b]{2}{*}{ Experiment } & \multicolumn{4}{|c|}{ Procedure for estimation } & \multirow[b]{2}{*}{$\mathrm{SD}$} \\
\hline & $0.92^{1}$ & Extrapolated F3 ${ }^{2}$ & Appropriate $\mathrm{Fpc}^{3}$ & $\mathrm{Fpc}=2.90^{4}$ & \\
\hline $\begin{array}{l}\operatorname{HMK}(\mathrm{Fpc}=3.04) \\
(\mathrm{n}=11)\end{array}$ & 2.270 & 2.264 & 2.261 & 2.259 & 0.042 \\
\hline $\begin{array}{l}\mathrm{IMK}(\mathrm{Fpc}=3.03) \\
\quad(\mathrm{n}=11)\end{array}$ & 2.466 & 2.460 & 2.462 & 2.460 & 0.27 \\
\hline $\begin{array}{l}\mathrm{CMK}(\mathrm{Fpc}=3.03) \\
(\mathrm{n}=29)\end{array}$ & 2.426 & 2.418 & 2.421 & 2.418 & 0.040 \\
\hline
\end{tabular}

HMK, milks from one herd; IMK, skim milks from individual cows; CMK, milks from cheese plants.

${ }^{1} 0.92$ for paracasein (33) in skim milk; $-\mathrm{FM} \times 1.01 / 100$ is added for milks containing fat.

${ }^{2}$ Extrapolated F3 (32) for paracasein: 0.891 for HMK and CMK; 0.927 for IMK (skim milk only).

${ }^{3}$ Paracasein using N (rennet whey) $\times 1.001 \times(1-\mathrm{FM} \times 1.01 / 100-\mathrm{Fpc} \times \mathrm{PM} \times 0.7463 / 100)$, except for IMK which does not include $\times 1.001$ or $\mathrm{FM} \times 1.01 / 100$.

${ }^{4}$ Substitute 2.90 for Fpc in footnote 3 .

(1994) gave estimated values of paracasein that were quite close for the milk in the HMK experiment, 2.261 and 2.264\%; those extrapolated values of F3 for the milk in the HMK experiment were used in the other two experiments. Estimated values using 0.92 for adjusting rennet whey $\mathrm{N}$ to its level in milk (van Boekel and Crijns, 1994) gave somewhat higher levels of paracasein, probably because that adjustment was developed on milks containing higher levels of protein. Mean levels of paracasein estimated on individual milks in the HMK experiments were identical to those estimated using the mean Fpc of 3.03 (data not shown). Standard deviations among milks in the IMK experiment were higher than those in the HMK and CMK experiments because IMK milks were from individual cows with a wider range of compositions.

The authors consider that the wider differences in means in this table and some others in this paper are of practical importance because they represent biases which, in turn, are important when analyses of large number of samples are involved in commercial applications. This is important even in analyses which have relatively larger standard deviations of analyses than the bias.

\section{Relationship of Paracasein to Other Protein Fractions in Milk}

Table 6 shows the proportions or ratios of paracasein to total milk protein, true milk protein (total $\mathrm{N}$ minus NPN), or casein, in three experiments using $\mathrm{N}$ conversion factors of 6.31, 6.35, 6.36 (van Boekel and Ribadeau-Dumas, 1987). The traditional factor of 6.38 was also used for easier comparison to other data published elsewhere.
The ratio of paracasein to casein ranged from 95.24 to $95.95 \%$ using $\mathrm{N}$ conversion factors of 6.36 and 6.31 , respectively, or from 96.00 to $96.71 \%$ using 6.38 as the factor. The standard deviations were quite low indicating relatively constant ratios; again it is not known how much of the variation was due to analytical error and how much to biological variability. Of all those measured, this ratio was the least variable.

The ratios of paracasein to "true" protein (total $\mathrm{N}$ minus NPN) were higher than those for paracasein to total protein (Table 6), as expected; standard deviations tended to be lower for the former, ranging from 0.00 to $0.23 \%$.

\section{Changes in Solute-Exclusion by Paracasein During Cheese-Making}

Several observations indicate that the solute-exclusion moisture in the paracasein decreased between the time of milk coagulation and the final cheese.

It is reasonable to expect that the solute-exclusion moisture of paracasein for large molecules, like proteins, might decrease if the micelles shrink; that is, the brush pile-like casein molecules (Kumosinski et al., 1991) compress together, expelling such water from the micelle. Figure 2 illustrates our concept of how solute exclusion occurs in milk and curd and how it changes. Serum proteins are approximately the same size as a casein molecule. It is evident that the former could or would be excluded from the casein micelle and, therefore, from the moisture contained therein. When solute exclusion or $h$ decreases, the release of the formerly solute-excluded water from the micelle would result in dilution of the $\mathrm{N}$ components in cheese whey. 
Table 6. Mean calculated levels of paracasein (pc) in milk from one herd (HMK), skim milks from individual cows (IMK), and milks from cheese plants (CMK), and their proportions to casein (CN), total protein (TP), and "true" protein $(\mathrm{Tr} P)$ using different factors for conversion of $\mathrm{N}$ to $\mathrm{pc}, \mathrm{CN}$, and $\mathrm{P}$.

\begin{tabular}{|c|c|c|c|c|c|c|c|c|}
\hline \multirow{2}{*}{$\begin{array}{l}\text { Conversion } \\
\text { factor }\end{array}$} & $\mathrm{pc}$ & $\mathrm{pc} / \mathrm{CN}$ & $\mathrm{pc} / \mathrm{TP}$ & $\mathrm{pc} / \operatorname{TrP}$ & $\mathrm{pc}$ & $\mathrm{pc} / \mathrm{CN}$ & $\mathrm{pc} / \mathrm{TP}$ & $\mathrm{pc} / \mathrm{TrP}$ \\
\hline & 6.31 & $6.31 / 6.36$ & $6.31 / 6.35$ & $6.31 / 6.35$ & 6.38 & $6.38 / 6.38$ & $6.38 / 6.38$ & $6.38 / 6.38$ \\
\hline $\begin{array}{l}\text { HMK } \\
\quad(\mathrm{n}=11)\end{array}$ & $\begin{array}{l}2.261 \\
(0.043)^{1}\end{array}$ & $\begin{array}{l}95.87 \\
(0.18)\end{array}$ & $\begin{array}{l}74.64 \\
(0.31)\end{array}$ & $\begin{array}{l}79.05 \\
(0.29)\end{array}$ & $\begin{array}{c}2.286 \\
(0.053)\end{array}$ & $\begin{array}{l}96.63 \\
(0.18)\end{array}$ & $\begin{array}{l}75.11 \\
(0.31)\end{array}$ & $\begin{array}{l}79.56 \\
(0.30)\end{array}$ \\
\hline $\begin{array}{l}\mathrm{IMK} \\
(\mathrm{n}=11)\end{array}$ & $\begin{array}{c}2.462 \\
(0.27)\end{array}$ & $\begin{array}{l}95.95 \\
(0.90)\end{array}$ & $\begin{array}{l}74.75 \\
(1.12)\end{array}$ & $\begin{array}{l}79.15 \\
(0.89)\end{array}$ & $\begin{array}{l}2.490 \\
(0.28)\end{array}$ & $\begin{array}{c}96.71 \\
(0.91)\end{array}$ & $\begin{array}{l}75.22 \\
(1.12)\end{array}$ & $\begin{array}{l}79.65 \\
(0.90)\end{array}$ \\
\hline $\begin{array}{l}\text { CMK } \\
(\mathrm{n}=29)\end{array}$ & $\begin{array}{c}2.421 \\
(0.040)\end{array}$ & $\begin{array}{l}95.24 \\
(0.27)\end{array}$ & $\begin{array}{l}74.37 \\
(0.46)\end{array}$ & $\begin{array}{l}78.80 \\
(0.46)\end{array}$ & $\begin{array}{c}2.447 \\
(0.040)\end{array}$ & $\begin{array}{l}96.00 \\
(0.27)\end{array}$ & $\begin{array}{l}74.84 \\
(0.46)\end{array}$ & $\begin{array}{l}79.30 \\
(0.46)\end{array}$ \\
\hline
\end{tabular}

${ }^{1}$ Numbers within parentheses represent SD among milk samples.

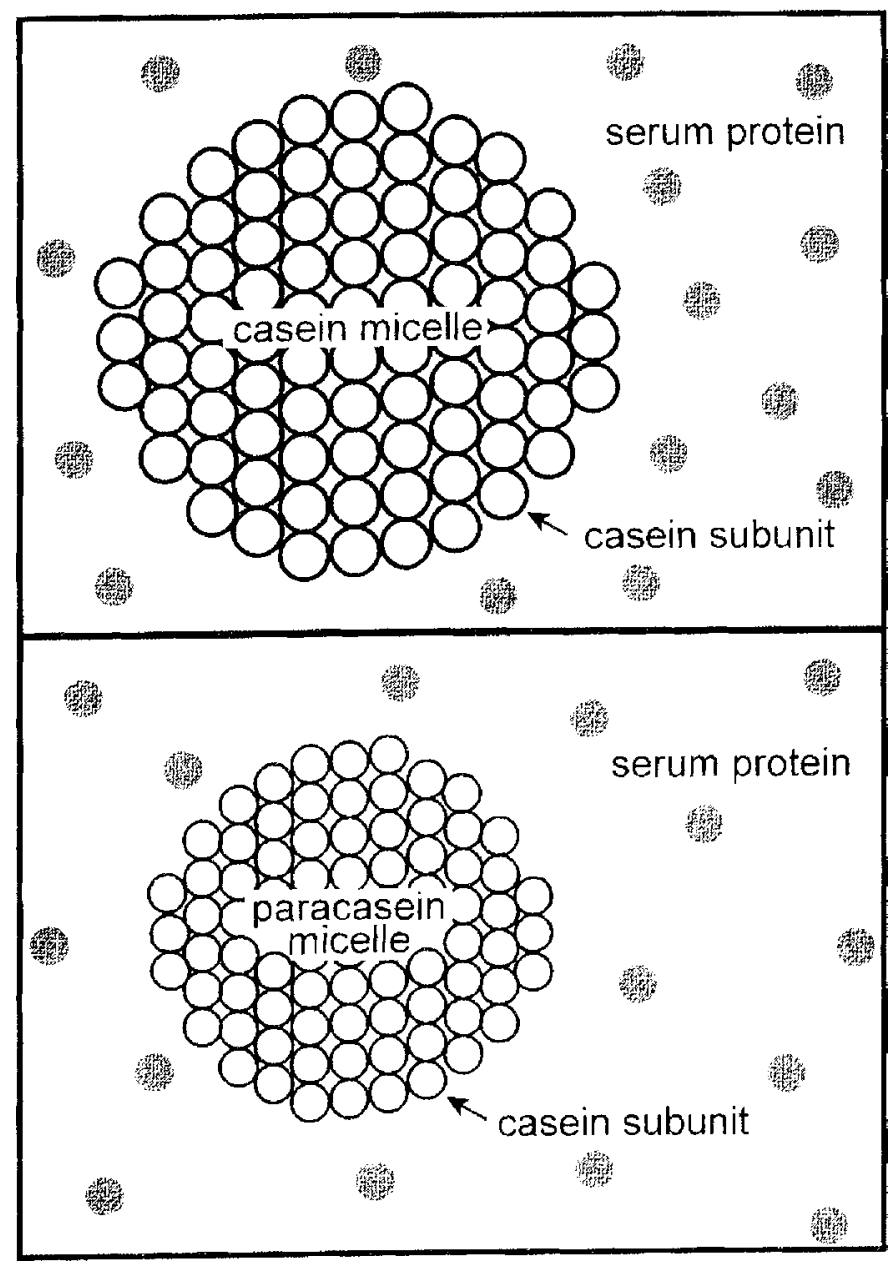

Figure 2. Schematic depiction of the hypothesized shrinking of the paracasein submicelles and micelles in milk during cheesemaking and the release of solute-exclusion water. The released water dilutes the surrounding intermicellar aqueous phase containing serum proteins. For illustration and calculation, the pooled solute-exclusion factor $(h)$ by paracasein to serum proteins reduced from 2.6 in milk to 0.8 in cheese.
Evidence that the $h$ of paracasein must have changed during cheesemaking is found in Table 7, which shows the ratio of the level of moisture to estimated levels of paracasein in curd and cheese at various points during cheesemaking. The ratio of water to paracasein decreased from approximately 3.6 at the time of draining the whey to 1.5 in the finished cheese; the latter is less than the 2.6 for the $h$ for SP found in milk (van Boekel and Walstra, 1989).

More evidence that the solute-exclusion properties of paracasein changed during cheesemaking, is that cheese apparently contains important amounts of serum proteins. Lo and Bastian (1998), for example, found that $\beta$-LG, $\alpha$-LA, BSA and immunoglobulins formed more than $1 \%$ of the protein in Havarti cheese containing $57 \%$ moisture in the fat-free cheese. O'Keefe et al. (1978) and de Koning et al. (1981) found that whey proteins formed about $1 \%$ of the protein in cheese.

Comparison of total $N$ in rennet whey and cheese whey. Further evidence of a change in $h$ of paracasein during cheesemaking can be found by comparing the levels of total $\mathrm{N}$ in rennet and cheese wheys, the rennet whey used for paracasein estimation; mean levels were 0.8466 and $0.8323 \%$, respectively (Table 1); after adjustment for dilution by added rennet, $\mathrm{CaCl}_{2}$, and acid, mean levels were 0.8474 and $0.8336 \%$ (Table 8), respectively. The differences were consistent, and significant $(P<0.01)$.

Initially, the reason for lower levels of $\mathrm{N}$ in cheese whey was not apparent. Table 9 shows that some weight was lost during cheese-making; evaporation during cooking was likely a major cause of the lost weight, tending to be more during November. Evaporation of moisture from whey in the open vat during cooking would, however, tend to increase, rather than decrease, the $\mathrm{N}$ in the cheese whey. If there had been no moisture loss from the whey during cooking, the 
Table 7. Ratio of paracasein (pc) to moisture (M) in curd and cheese during manufacture.

\begin{tabular}{|c|c|c|c|c|c|}
\hline \multirow{2}{*}{$\begin{array}{l}\text { Stage of } \\
\text { manufacture }\end{array}$} & \multicolumn{3}{|c|}{ Moisture content } & \multirow{2}{*}{$\begin{array}{l}\text { Estimated }^{1} \\
\text { paracasein } \\
\text { in curd } \\
\text { or cheese }\end{array}$} & \multirow{2}{*}{$\begin{array}{l}\text { Ratio } \\
\text { M:pc }\end{array}$} \\
\hline & Trial 1 & Trial 2 & Mean & & \\
\hline & & & & & \\
\hline Drain whey & 57.4 & 55.8 & 56.6 & 15.7 & 3.6 \\
\hline $1 \mathrm{~h}$ Later & 43.5 & 44.1 & 43.8 & 21.0 & 2.1 \\
\hline Milling & 40.7 & 41.2 & 41.0 & 22.2 & 1.8 \\
\hline Cheese & 35.1 & 34.9 & 35.0 & $23.9^{2}$ & 1.5 \\
\hline Fat in cheese & 34.8 & 35.0 & 34.9 & & \\
\hline
\end{tabular}

\footnotetext{
${ }^{1}$ Paracasein was estimated by multiplying the salt-free, whey-solids-free, dry cheese (\%) by 0.428 (the fat-free fraction of the salt-free, whey solids-free, dry cheese in the cheese) and dividing by 1.08 to remove the minerals associated with the paracasein. Neither fat nor protein was measured in the curd samples.

${ }^{2}$ Estimated from mean protein of $24.24 \%$ (Table 1) in cheese, containing $98.5 \%$ paracasein (Table 10).
}

level of $\mathrm{N}$ in the cheese whey would have been lower than that observed, in the order of $1 \%$.

We feel that the explanation of the lower protein in cheese whey is that the coagulated paracasein lost solute-exclusion water during cooking, diluting slightly the $\mathrm{SP}$ and $\mathrm{PP}$ in the whey. It is possible that $\mathrm{N}$ in cheese whey might be used to estimate paracasein, using a lower Fpc, but caution should be used because

Table 8. Comparison of total protein $(\times 6.38)$ in rennet whey and in cheese whey in the HMK experiment using milk from one herd.

\begin{tabular}{|c|c|c|c|c|}
\hline Lot & Vat & $\begin{array}{l}\text { Rennet } \\
\text { whey }\end{array}$ & $\begin{array}{l}\text { Cheese } \\
\text { whey }\end{array}$ & Difference \\
\hline & & & $-(\%)$ & 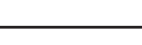 \\
\hline 1 & $\begin{array}{l}1 \\
2\end{array}$ & 0.871 & $\begin{array}{l}0.854 \\
0.855\end{array}$ & $\begin{array}{l}0.017 \\
0.016\end{array}$ \\
\hline 2 & $\begin{array}{l}1 \\
2\end{array}$ & 0.864 & $\begin{array}{l}0.846 \\
0.841\end{array}$ & $\begin{array}{l}0.018 \\
0.023\end{array}$ \\
\hline 3 & $\begin{array}{l}1 \\
2\end{array}$ & 0.862 & $\begin{array}{l}0.837 \\
0.845\end{array}$ & $\begin{array}{l}0.025 \\
0.017\end{array}$ \\
\hline 4 & $\begin{array}{l}1 \\
2\end{array}$ & 0.822 & $\begin{array}{l}0.812 \\
0.811\end{array}$ & $\begin{array}{l}0.010 \\
0.011\end{array}$ \\
\hline 5 & $\begin{array}{l}1 \\
2\end{array}$ & 0.851 & $\begin{array}{l}0.842 \\
0.843\end{array}$ & $\begin{array}{l}0.009 \\
0.008\end{array}$ \\
\hline 6 & $\begin{array}{l}1 \\
2\end{array}$ & 0.868 & $\begin{array}{l}0.854 \\
0.855\end{array}$ & $\begin{array}{l}0.014 \\
0.013\end{array}$ \\
\hline 7 & $\begin{array}{l}1 \\
2\end{array}$ & 0.840 & $\begin{array}{l}0.824 \\
0.824\end{array}$ & $\begin{array}{l}0.016 \\
0.016\end{array}$ \\
\hline 8 & $\begin{array}{l}1 \\
2\end{array}$ & 0.866 & $\begin{array}{l}0.849 \\
0.847\end{array}$ & $\begin{array}{l}0.017 \\
0.019\end{array}$ \\
\hline 9 & $\begin{array}{l}1 \\
2\end{array}$ & 0.829 & $\begin{array}{l}0.818 \\
0.815\end{array}$ & $\begin{array}{l}0.011 \\
0.014\end{array}$ \\
\hline 10 & $\begin{array}{l}1 \\
2\end{array}$ & 0.805 & $\begin{array}{l}0.798 \\
0.800\end{array}$ & $\begin{array}{l}0.007 \\
0.005\end{array}$ \\
\hline 11 & $\begin{array}{l}1 \\
2\end{array}$ & 0.835 & $\begin{array}{l}0.817 \\
0.823\end{array}$ & $\begin{array}{l}0.018 \\
0.012\end{array}$ \\
\hline $\begin{array}{l}\text { Mean } \\
\text { Adjusted means1 }\end{array}$ & & $\begin{array}{l}0.8466 \\
0.8474\end{array}$ & $\begin{array}{l}0.8323 \\
0.8336\end{array}$ & $\begin{array}{l}0.0144 \\
0.0138\end{array}$ \\
\hline
\end{tabular}

${ }^{1}$ Adjusted for dilution of milks. of possible variation in solute-exclusion by the paracasein micelles and in evaporation during cooking.

Another possible reason for the lower level of $\mathrm{N}$ in cheese whey than in rennet whey is that the starter bacteria utilized some of the $\mathrm{N}$ for growth. It is well known that lactic bacteria require a source of peptides and amino acids for growth. It is probable that those peptides and amino acids are removed from the growth medium to become part of the cells. But we are not aware of work showing that growth of starter bacteria results in measurably lower levels of $\mathrm{N}$ in whey during cheesemaking. If utilization of $\mathrm{N}$ in whey by starter indeed occurred, it would have an impact on the above discussion of changes in $h$ during early cheesemaking, but not on changes in $h$ by the end of cheesemaking.

Causes of changes in $h$ during cheesemaking. The $\mathrm{pH}$ decreased while temperature, and time and degree of syneresis increased during the time that the $h$ appeared to decrease. Hence, these factors might be causes of the apparent decreased solute-exclusion by the paracasein. Concentration only, during syneresis, seemed not to be the major cause, if at all, because

Table 9. Mass balance of weights of all inputs to all outputs in the HMK experiment using milk from one herd.

\begin{tabular}{lllll}
\hline Trial & Date & Vat 1 & Vat 2 & Mean \\
\cline { 3 - 5 } & mo d & & & \\
\cline { 3 - 5 } 1 & $05-11$ & 99.21 & 99.10 & 99.16 \\
2 & $05-24$ & 99.37 & 99.40 & 99.38 \\
3 & $06-07$ & 99.02 & 99.39 & 99.20 \\
4 & $06-21$ & 99.47 & 99.45 & 99.46 \\
5 & $07-05$ & 99.38 & 99.47 & 99.42 \\
6 & $09-13$ & 99.52 & 99.90 & 99.71 \\
7 & $09-27$ & 99.41 & 99.37 & 99.39 \\
8 & $10-11$ & 99.15 & 99.13 & 99.14 \\
9 & $10-25$ & 99.21 & 99.14 & 99.18 \\
10 & $11-14$ & 98.72 & 98.50 & 98.61 \\
11 & $11-28$ & 99.08 & 98.95 & 99.02 \\
Mean & & 99.23 & 99.25 & 99.24 \\
\hline
\end{tabular}


Table 10. Estimated proportions of $\mathrm{N}$ fractions in cheese.

\begin{tabular}{lrl}
\hline & $\%$ & $\mathrm{SD}^{1}$ \\
\hline Serum protein N & & \\
Caseomacropeptide (CMP) N $^{3}$ & 1.00 & \\
NPN (from milk) & 4.10 & 0.004 \\
Proteose-peptone N (from milk) $^{5}$ & 0.24 & 0.02 \\
Paracasein and its hydrolysis products $^{6}$ & 0.15 & 0.01 \\
Total & 98.51 & 0.03 \\
\hline
\end{tabular}

${ }^{1} \mathrm{SD}=$ standard deviations among 22 vats.

${ }^{2}$ Estimated for purpose of calculation from data of O'Keefe et al. (26), de Koning et al. (9), and Lo and Bastian (21).

${ }^{3} \mathrm{CMPN}$ was $4 \%$ of casein $\mathrm{N}$; solute-exclusion factor of 0.55 in cheese whey and in cheese.

${ }^{4}$ Solute-exclusion factor of 0.2 in cheese whey and in cheese.

${ }^{5}$ Solute-exclusion factor of 0.55 in cheese whey and in cheese.

${ }^{6}$ By difference; 22 vats of cheese.

decreased or increased centrifugation of the rennet coagulum during rennet whey preparation in a small unreplicated trial (unpublished) did not change the level of N ( $P>0.05)$. Similarly, Buisse (1999) found that syneresis of the gel did not change the $h$ of the paracasein, nor did ultrafiltration nor $\mathrm{pH}$. On the other hand, increased temperature during cooking may decrease swelling of the paracasein micelle and soluteexcluding moisture. The apparent reduced solute exclusion may be related to two other physical phenomena affected by temperature. In one, viscosity of skim milk decreases relative to that of rennet whey as temperature increases. This reflects an apparent decrease in voluminosity of the casein micelle (Webb and Johnson, 1965). In the second, a decrease in temperature in one part of a block of cheese results in movement of moisture from the warmer part to the cooler part (Geurts, 1978; Reinbold and Ernstrom, 1988). The swelling of the paracasein micelles apparently decreased in the warmer cheese. In both case the swelling of the casein or paracasein decreases at the higher temperatures which may be related to the apparent change in $h$ at higher temperatures during cheesemaking.

\section{Transfer of Paracasein from Milk to Cheese and Wheys}

An important criterion of the usefulness of the analytical procedure for paracasein is whether the paracasein measured in milk is equal to that obtained in cheese, curd fines and whey. If they are not equal, then one is uncertain whether the paracasein measured in milk, and its method of calculation are correct. Quantities of paracasein or its hydrolysis products in cheese, curd fines, salted whey, whey during cheddaring, and in whey during cooking were either measured or esti- mated in each vat, as follows. All of the $\mathrm{N}$ in the curd fines was considered as paracasein $\mathrm{N}$.

The level of hydrolysis products from paracasein in salted whey was estimated as the difference between the level of $\mathrm{N}$ in the fat-free, salt-free portion of the salted whey and the level of $\mathrm{N}$ in cheese whey. This was not a simple calculation because the unsalted whey was a blend of wheys, both during cooking and during cheddaring, and because hydrolyzed paracasein is released into whey during cheddaring (Emmons et al., 1990; Emmons and Beckett, 1990). In three beaker experiments, mean levels of protein $(\mathrm{N} \times 6.38)$ in whey at the end of cooking was $0.90064 \%$, and of whey at the end of cheddaring, $0.97654 \%$; mean amounts of whey were 480 and $33 \mathrm{ml}$, respectively. Those proportions of weights and composition were applied to the present experiment, resulting in a level of $0.005 \%$ less protein $(\mathrm{N} \times 6.38)$ in the whey at the end of cooking than in the total blend and $0.076 \%$ more protein in the whey during cheddaring, i.e., means of 0.827 , 0.832 , and $0.903 \%$, respectively; the $0.076 \%$ was considered to be hydrolyzed paracasein. For estimation of hydrolyzed paracasein in salted whey, the level of protein was $0.005 \%$ less than that in the blended unsalted whey.

For paracasein in cheese, it is difficult to visualize how one could measure it because of the continued chymosin action during cheese-making; for example, the mean level of $\mathrm{N}$ in salt-free, fat-free whey collected during pressing was $41 \%$ higher than in cheese whey. It might be possible to estimate the amount of paracasein by measuring the amounts of the residual proteins and other fractions from whey in the cheese, but it was not done in this experiment. Instead, the level of paracasein in cheese was estimated as the difference between the total cheese $\mathrm{N}$ and the estimated levels of milk NPN, milk PP N, milk SP N and CMP N in the moisture part of the cheese; an $h$ of 0.2 was used for milk NPN and 0.55 for CMP N (4\% of casein N) and milk PP N going from milk to whey and from whey to cheese. The SP N was taken as $1 \%$ of the TN of cheese, after considering the results of experiments by O'Keefe et al. (1978), de Koning et al. (1981), and Lo and Bastian (1998). The level of SP N in the moisture in cheese was more than twice that which one would expect from its level in milk and whey. The mean levels of milk NPN, milk PP N, CMP N and SP N in cheese were estimated to be $0.24,0.15,0.10$ and $1.0 \%$, respectively, giving a level of paracasein and its hydrolysis products in cheese of $98.51 \%$ (Table 10).

Mean quantities of paracasein were estimated to be $98.21,0.20,0.25$, and $0.19 \%$ in the cheese, curd fines, salted whey, and whey during cheddaring, respectively, as percentages of paracasein estimated to be in 
Table 11. Apparent recovery of paracasein from milk in wheys and cheese.

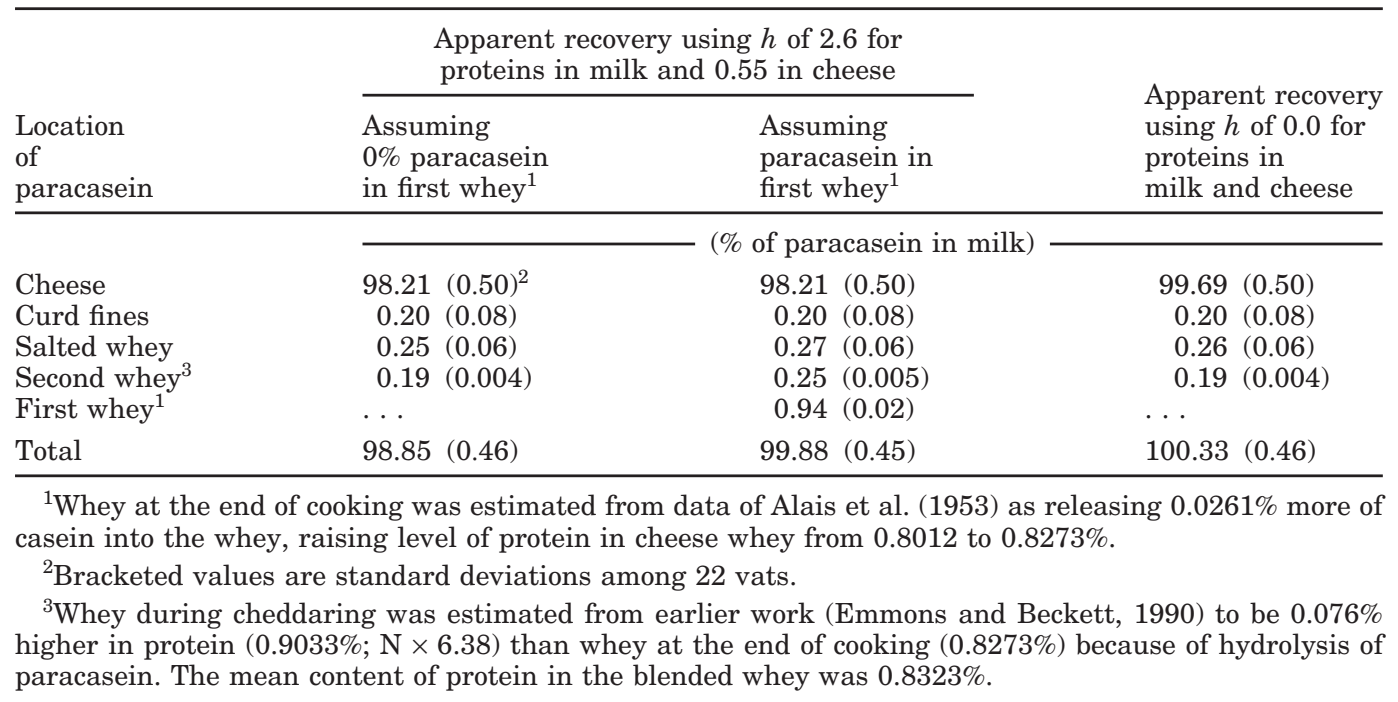

the milk. The percentage of milk paracasein estimated to be transferred to cheese varied significantly $(P<$ $0.01)$ among the 11 days of cheese making, but was highly correlated $(P<0.01)$, as expected, with the percentages of milk $\mathrm{N}$ going to cheese (Table 3 ).

The mean total recovery of milk paracasein was $98.85 \%$ (Table 11), which was significantly less $(P<$ 0.05 ) than $100 \%$. The recovery of $98.85 \%$ of paracasein appears not to agree with our data in Table 3 showing recovery of $99.92 \%$ of $\mathrm{N}$ from milk in cheese and whey, nor with the conclusions of van den Berg et al. (1996); the latter seemed to be able to account for disposition of almost all of the paracasein in milk, although a mass balance of weight of paracasein was not attempted; our mass balance study of paracasein used $\mathrm{N}$ instead of weight of protein.

A number of possibilities exist for the lower than expected recovery of paracasein. Firstly and obviously, there could have been biases in analyses and measurements. Secondly, paracasein in cheese may have been higher than estimated here, but not likely, in our opinion. In this respect, it would be useful to determine levels of SP in wheys during cheese making to help in obtaining a mass balance of paracasein. Thirdly, the estimated levels of whey components derived directly from milk may be too high in salted whey and in whey during cheddaring, because of the release of soluteexcluding moisture that was not measured.

A fourth possibility is that the $h$ of 2.6 is too high. A lower $h$ of casein in milk would reduce the level of estimated paracasein in milk. The right column in Table 11 shows that an $h$ of 0 would result in $100.33 \%$ recovery of paracasein, not significantly different from $100 \%(P>0.05)$; however, we believe that a possibility of $h-0$ is not probable in view of the rather strong evidence of the existence of an $h$ of about 2.6 of paracasein in milk for SP (van Boekel and Walstra, 1989; Buijsse, 1999), and the difference in the levels of $\mathrm{N}$ in rennet and cheese whey, in Table 8.

A fifth possible location for the missing paracasein was in the hydrolyzed form in the whey expressed from the curd during cooking. Alais et al. (1953) published graphs showing the changes in $\mathrm{N}$ soluble in $12 \%$ - and $2 \%$-soluble TCA solutions due to chymosin action in sodium caseinate solution. The 12\%-TCA-soluble N reached a plateau in about $20 \mathrm{~min}$. The $2 \%$-TCA-soluble $\mathrm{N}$ increased more than two times more quickly during the same time but continued to increase thereafter; about $1 \%$ of additional casein was hydrolyzed during 100 min after the plateau of $12 \%$-TCA-soluble $\mathrm{N}$ had been reached. The second column of data in Table 11 shows that the possible additional hydrolysis of $1 \%$ of the casein, releasing $0.261 \%$ of protein $(\mathrm{N} \times$ 6.38) into the whey during cooking, would have increased recovery of milk paracasein to $99.88 \%$. It is quite possible for secondary hydrolysis of paracasein during cooking, further to the primary hydrolysis releasing CMP. Hydrolysis of as much as $1 \%$ of the paracasein is not, however, reasonable within the context of this study because it would require more soluteexclusion moisture than was likely in the paracasein to dilute the rennet whey containing hydrolyzed paracasein to the level of $\mathrm{N}$ found in the cheese whey.

In summary of this portion of the paper, the reason for the apparently incomplete recovery of paracasein from milk in cheese and wheys is not apparent at this time.

\section{Fate of Proteose-Peptone During Coagulation}

A previous study (van Boekel and Crijns, 1994) had concluded that about $75 \%$ of the PP fraction of milk 
was retained in the rennet coagulum; this was based on disappearance of two PP components in gel-permeation chromatography and on calculations of levels of CMP in the rennet whey. These calculations estimated the level of PP N from rennet whey and adjusted it to its level in skim milk by subtracting milk NPN and CMP N from the crude PP N in rennet whey, as follows:

\section{$0.92 \times$ measured crude PP $\mathrm{N}$ in rennet whey -0.05 $\times$ milk casein $\mathrm{N}-0.992 \times \mathrm{NPN}$ in milk filtrate;}

the 0.05 represented $5 \%$ of casein $\mathrm{N}$ split by chymosin as CMP N; crude PP $\mathrm{N}$ in rennet whey included the milk NPN. In the HMK experiment, however, that calculation estimated that $55 \%$ of $\mathrm{PP}$ in the original milk was retained in the coagulum, compared to $75 \%$ retention of PP in the previous study (van Boekel and Crijns, 1994), the IMK experiment.

A different interpretation of the data is possible. One point of difference is that we calculate that only approximately $4 \%$ of casein $\mathrm{N}$ is likely split from casein by chymosin as CMP N, not 5\% (van Boekel and Crijns, 1994). Alais et al. $(1953 ; 1984)$ found that $3.8 \%$ of casein $\mathrm{N}$ was hydrolyzed in the primary reaction, but further slower proteolytic action occurred. A value of $4 \%$ of CMP N in casein $\mathrm{N}$ seems to be reasonable because we calculated that the N in CMP was $33.7 \%$ of $\kappa$-CN N from the amino acid sequence of $\kappa$-CN (Swaisgood, 1992). Levels of $\kappa$-CN in casein have been mostly reported as 12 to 13\% (Davies and Law, 1983; Alais, 1984; Walstra and Jenness, 1984; Brulé and Lenoir, 1986; Brown, 1988; Groen et al., 1994), with one at $10 \%$ (Ng-Kwai-Hang and Pelissier, 1989); the proportion of CMP N in casein $\mathrm{N}$ would then be $0.034,0.040$ and 0.044 for 10,12 and $14 \%$ of $\kappa-\mathrm{CN}$ in casein, respectively. Reduction of 0.05 to 0.04 reduced apparent retention of PP N in the coagulum from 55 to $37 \%$ in our study and 73 to $50 \%$ in the previous study (van Boekel and Crijns, 1994).

Further, the distributions of $\mathrm{N}$ in rennet whey, compared to levels of $\mathrm{N}$ components from milk in rennet whey estimated using adjustment [1], are shown in Table 12. Calculations showed that, using 0.04 for the proportion of CMP $\mathrm{N}$ in casein $\mathrm{N}$ would have accounted for all the $\mathrm{N}$ in rennet whey from the SP N, PP N, and NPN in the CMK milks $(0.1451$ vs $0.1450 \%)$ and slightly more than the $\mathrm{N}$ estimated from the HMK and IMK milks ( 0.1327 vs $0.1335 \%$ and 0.1392 vs $0.1422 \%$, respectively). The relatively low standard deviations of differences between totals of $0.0012,0.0007$ and $0.0039 \%$ for individual milks, respectively, indicate good relative agreement between the observed and calculated levels. Calculations (not shown) showed that proportions of CMP N in casein $\mathrm{N}$ of $0.034,0.033$ and
0.04 would have accounted for all the $\mathrm{N}$ in rennet whey from the SP N, PP N, and NPN in the HMK, IMK, and CMK milks, respectively. Assuming that $4 \%$ of casein was split as CMP, there would have been $10(P<0.05)$, $15(>0.05)$ and $0 \%$ of PP retained in the curd in the HMK, IMK, and CMK experiments, respectively. While the possibility of some retention of $\mathrm{PP}$ in paracasein cannot be excluded, retention would appear to be low or nonexistent.

Table 12 also reveals that measured levels of SP N in rennet whey were higher than those estimated from their level in milk. If some of the original PP in milk was in the SP fraction of rennet whey, this would account for a portion of the apparent transfer of PP to paracasein and cheese curd (van Boekel and Crijns, 1994). A possible explanation of the increased levels of SP N in rennet whey is that some of the PP interacted with the SP during the denaturation step for PP $\mathrm{N}$ estimation, in the same way that casein interacts with SP when milk is heated. The levels of apparent SP N in the rennet wheys were significantly higher $(P$ $<0.05$ ) by $0.0069,0.0052$, and $0.0071 \%$ in the HMK, IMK, and CMK experiments, respectively. These were equivalent to about 30,26 and $32 \%$ of the PP N in the milk. Interaction of PP with serum proteins may explain the disappearance of PP from whey in making ricotta cheese (Modler and Emmons, 1989a, 1989b).

In summary, the apparent retention of $\mathrm{PP}$ in rennet curd was 10, 15, and 0\% in the HMK, IMK, and CMK experiments, respectively, which is much lower than previously reported (van Boekel and Crijns, 1994). The lower values were because 0.04 was used as the proportion of paracasein $\mathrm{N}$ to casein $\mathrm{N}$, and because apparent levels of the SP fraction in the rennet whey were higher than expected from their level in milk.

\section{Relationship Among Methods of Estimation of Paracasein}

It is of interest to compare levels of paracasein as measured in this paper with levels estimated in other, earlier cheese yield equations. Table 13 shows that the level of paracasein using the factor of 6.31 in the HMK experiment was lower than those estimated using $\mathrm{N} \times 6.38$ by paracasein in this study, by Casein 0.1 (Van Slyke and Publow, 1910; Van Slyke and Price, 1949) and by Casein $\times 0.96$ (Emmons et al., 1990), that is, 2.261 versus $2.286,2.286$ and $2.271 \%$, respectively. The relative results in experiments IMK and CMK were similar to those in HMK.

\section{DISCUSSION}

It is well recognized that the protein and casein contents of milk vary. It is also well recognized that 
Table 12. Distribution of $\mathrm{N}$ in measured fractions of rennet whey, compared to levels of those fractions in rennet whey estimated from their levels in herd milks, individual milks and cheese plant milks.

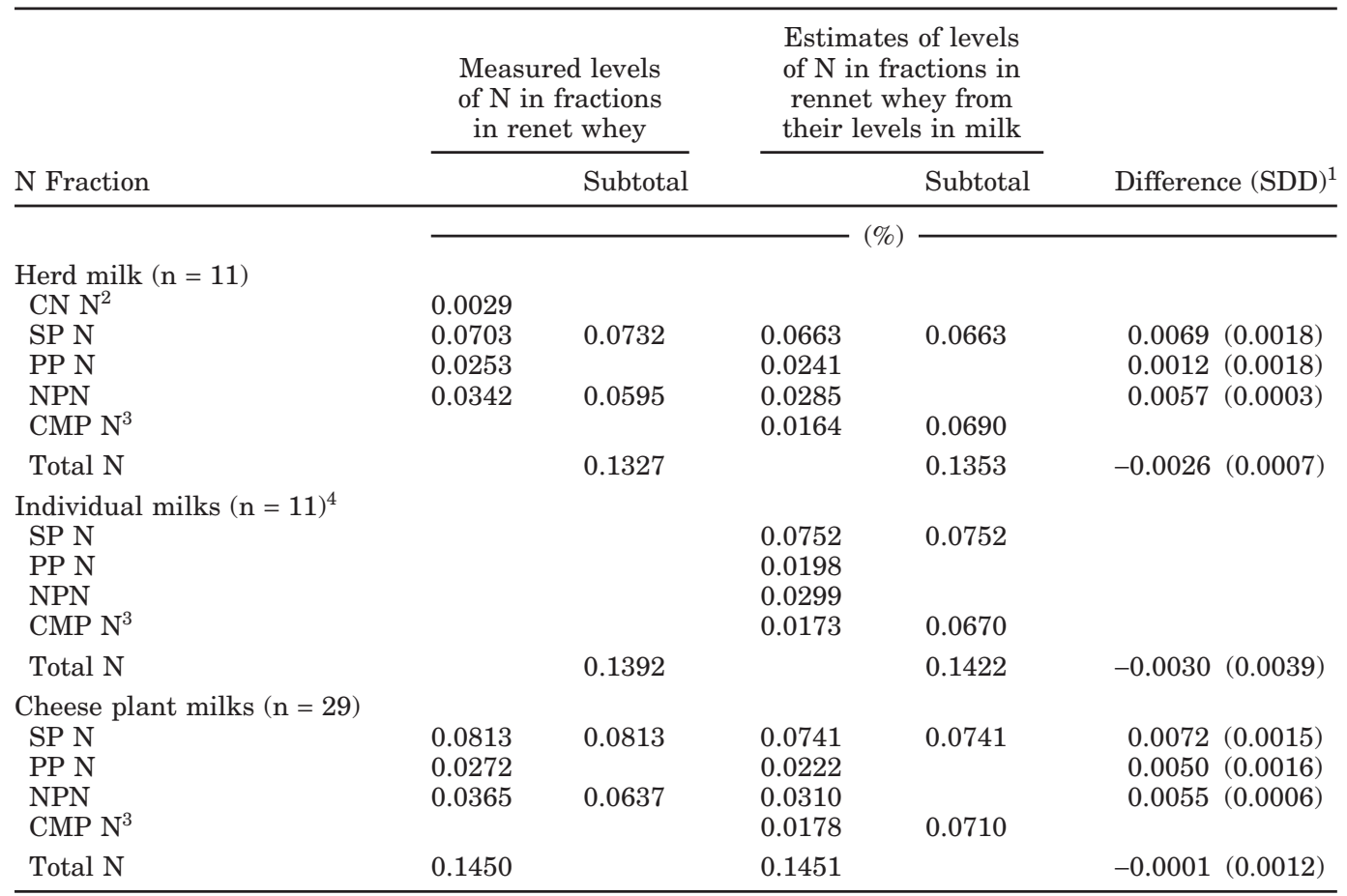

\footnotetext{
${ }^{1}$ Standard deviation of the differences between measured fraction and the level in whey estimated from the level of the fraction in milk.

${ }^{2} \mathrm{CN} \mathrm{N}=$ casein $\mathrm{N}$; SP N = serum protein $\mathrm{N}$; PP N = proteose-peptone $\mathrm{N}$; CMP N = caseomacropeptide $\mathrm{N}$.

${ }^{3}$ Assumes that $\mathrm{CMPN}=0.04 \%$ of casein $\mathrm{N}$.

${ }^{4}$ Skim milks; numbers were calculated from data of van Boekel and Crijns (1994).
}

different genetic variants of milk and varied levels of NPN influence the casein number or the proportion of casein in total milk protein-even in true milk protein. (Puhan and Jakob, 1994; van den Berg et al., 1996). Because of this variation, cheese yield has been related preferably to casein, until now. However, the proportion of $\kappa$-casein in casein is known to vary (van den Berg et al., 1992), certainly in individual cows (de Koning et al., 1981). The higher the proportion of $\kappa$-casein in casein, the more $\mathrm{N}$ as CMP is lost in the whey, relative to the amount of casein in the milk. Yield per unit of casein would be lower, unless there are other over-riding factors such as reduced curd losses in the whey (van den Berg et al., 1992). Thus, theoretically, paracasein is likely to be a slightly better measure of cheese yield than casein; although in this study, the ratio of paracasein to casein was relatively constant (Table 6).

Analysis of milk for paracasein for the purpose of yield control may have certain practical advantages over that for casein. It is easier to produce rennet whey for paracasein than acid filtrates for casein, and it is

Table 13. Relationship between means of measured and other estimates of paracasein.

\begin{tabular}{|c|c|c|c|c|}
\hline \multirow[b]{2}{*}{ Experiment } & \multicolumn{2}{|c|}{ Measured paracasein } & \multirow{2}{*}{$\frac{\text { Casein }-0.1^{1}}{\mathrm{~N} \times 6.38}$} & \multirow{2}{*}{$\frac{\text { Casein } \times 0.96^{2}}{\mathrm{~N} \times 6.38}$} \\
\hline & $\mathrm{N} \times 6.31$ & $\mathrm{~N} \times 6.38$ & & \\
\hline & & & ) & 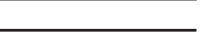 \\
\hline $\mathrm{HMK}^{3}$ & 2.261 & 2.286 & 2.286 & 2.271 \\
\hline IMK & 2.462 & 2.490 & 2.475 & 2.472 \\
\hline CMK & 2.421 & 2.447 & 2.449 & 2.447 \\
\hline
\end{tabular}

${ }^{1}$ Van Slyke and Price equation (Van Slyke and Publow, 1910; Van Slyke and Price, 1949).

${ }^{2}$ General equation (Emmons et al., 1990).

${ }^{3} \mathrm{HMK}$, milks from one herd; IMK, skim milks from individual cows; CMK, milks from cheese plants. 
usually more convenient to use infrared instruments for analysis of rennet whey than the Kjeldahl apparatus for analysis of acid filtrates. Further, the results in the HMK experiment suggest somewhat lower variability in analysis of the subsamples of rennet whey than in analysis of the acid filtrates; standard deviations of analyses were 0.0019 and $0.0053 \%$ of protein, respectively.

The procedure of van Boekel and Walstra (1989) and subsequent descriptions for preparation of rennet whey for estimation of paracasein seemed to be reasonable. Their use of solute-exclusion of whey $\mathrm{N}$ fractions by paracasein in the calculation of paracasein appears to be essential (Table 7). This study did not verify the $h$ of the fractions but it would appear to be prudent that they be verified in other studies, particularly the $h$ of 1.5 for CMP, for which there appears to be no published data. The ruggedness of the preparation procedure should be checked to assess whether such things as heating the curd to hasten whey expulsion (van den Berg et al., 1996) change $h$ of paracasein and the level of $\mathrm{N}$ in whey.

It is essential that the procedure for estimation of paracasein gives results that can accurately predict the paracasein recovered in cheese and that is lost in wheys, for yield formulas that are the sum of the components in the cheese recovered from milk (Emmons et al., 1990). In this study, the total estimates of paracasein in cheese, curd fines and salted whey were lower than the amounts of paracasein estimated in milk. Possible reasons for discrepancies were discussed earlier and are summarized as follows: biases in analyses and measurements; underestimation of paracasein in cheese; underestimation of paracasein $\mathrm{N}$ lost in salted and cheddaring wheys, and possibly whey during cooking; and overestimation of paracasein in milk because the $h$ may be too high. These discrepancies need to be resolved; otherwise, the amount of protein in cheese needs to be estimated, pragmatically, as a proportion of the protein, casein or paracasein in milk. The validity of the estimate of paracasein in milk remains in doubt when its disposition in cheese and wheys is not certain.

Detailed studies of levels of whey protein fractions in different varieties of cheese are needed to estimate more accurately the amount of paracasein in cheese. Further, the estimates of paracasein in cheese were based on a pooled $h$ of whey $\mathrm{N}$ fractions (excluding NPN) of 0.55 which was within the maximum of 1.5 (Table 7), the latter conforming to the moisture content of the finished cheese (Table 8); the 0.55 may be high or low.

Initial estimates of paracasein were based on adjustment of the individual $\mathrm{N}$ fractions of SP, PP, CMP and
NPN (from milk) in rennet whey to their levels in milk, using the respective $h$ of $2.6,2.6,1.5$ and 0.2 . It was possible to pool the $\mathrm{N}$ fractions on a weighted basis and add 1.08 (for paracasein and associated salts) to give a factor, Fpc, of 3.0. The use of this Fpc for adjustment [2] for all the milks gave values of paracasein that were close to those estimated from individual compositions of rennet whey (Table 5). Adjustment [2] and Fpc were independent of the protein and fat content of the milk.

Solute-exclusion by paracasein, and its changes during cheesemaking, can be visualized by considering the paracasein and its micelles as a fine sponge, excluding large solutes, and including only water and small molecules. During cheesemaking, the sponge shrinks, expelling the liquid free of large solutes, and diluting the surrounding whey (Figure 2) inside the curd. The shrinkage was related to lowered $\mathrm{pH}$, increased temperature and longer time. The shrinkage would appear to be caused by intra- or intermolecular changes in the structure of the caseins in the subunits or micelles. The sponge concept of solute exclusion and its changes (Figure 2) has been easier for the authors to understand and conceptualize than steric exclusion at the surface of micelles (Walstra and Jenness, 1984; van Boekel, 1994).

A hypothesis that the $h$ of paracasein decreased during cheesemaking fits certain observations. The $h$ of paracasein must have changed to permit a ratio of moisture to paracasein in the finished cheese of 1.5 (Table 7) and to permit the presence of serum proteins. Further, lower levels of $\mathrm{N}$ were found in cheese whey than in rennet whey. The apparent change in $h$ during cheesemaking may be related to a decrease in voluminosity of casein micelles at higher temperatures in skim milk (Webb and Johnson, 1965) and to shrinking of paracasein in cheese when moisture moves from warmer to cooler parts of the cheese (Geurts, 1978; Reinbold and Ernstrom, 1988).

There is the question of the composition of the measured paracasein. In addition to the caseins, measurement on whole milk by Kjeldahl would include the fat globule membrane proteins (van den Berg et al., 1996). In experiments HMK and CMK, small amounts of casein-like (acid-precipitable) precipitate were present in rennet whey (Table 13), begging the question of its nature. While previous work estimated that $75 \%$ of the PP in milk was included in curd (van Boekel and Crijns, 1994), this study (Table 12 indicates that very little, if any, was included.

A quantitative definition of paracasein $\mathrm{N}$ in milk would necessarily include the method of preparing the rennet whey and the method of calculation and adjustment of the level of $\mathrm{N}$ in rennet whey to that in milk. 
The Fpc of 3.0 for rennet whey could be used, which includes the pooled $h$ of the $\mathrm{N}$ fractions in rennet whey and the 1.08 for paracasein and associated salts. Estimation of paracasein in milks containing fat would include fat globule membrane proteins and, in heated milk, denatured whey proteins (van den Berg et al., 1996). The latter would be useful for yield prediction. Based on our interpretation of the data presented in these trials, the paracasein may include only a small portion of the PP fraction in milk.

The results of these experiments are encouraging to pursue further the use of paracasein and its measurement in control of cheesemaking, a conclusion shared with van den Berg et al. (1996).

\section{ACKNOWLEDGMENTS}

The authors wish to acknowledge the technical assistance of Carol Campbell, Ralph Cooligan, Harold Daley, Cheryl Defelice, and Ulrich Bollinger. We also thank Dr. M Kalab for preparation of the figures and for suggestions for the paper.

\section{REFERENCES}

Alais, C. 1984. Science du lait: principle des techniques lathers. 4th ed. Edition Sepia, Paris.

Alais, C., G. Moquot., H. Nitschmann, and P. Zahler. 1953. (Translation: Rennet and its action on the casein of milk. VII. On the splitting of nonprotein nitrogen from casein by rennet and its action during the primary reaction of the renneting of milk.) Helv. Chim. Acta 34(7):1955-1968.

Babcock, S. M. 1895. Experiments in the manufacture of cheese. 11th Ann. Rep. Agric. Exp. Stn. Univ. Wisconsin, Madison.

Brown, R. J. 1988. Milk coagulation and protein denaturation. In Fundamentals of Dairy Chemistry. 3rd ed. N. P. Wong, R. Jenness, M. Keeney and E. H. Marth, ed. Van Nostrand Reinhold Co., New York.

Brulé, G., and J. Lenoir. 1986. The coagulation of milk. In Cheesemaking Science and Technology, 2nd ed. Ed. by A. Eck. Lavoisier Pub. Inc., New York.

Buijsse, C. 1999. Cheese from ultrafiltered milk-whey proteins and chymosin activity. PhD. Thesis. Wageningen Agricultural University, The Netherlands.

Davies, D. T., and A. J. R. Law. 1983. Variation in the protein composition of bovine casein micelles and serum casein in relation to micellar size and milk temperature. J. Dairy Res. 50:67-75.

de Koning, P. J., R. de Boer, P. Both, and P. F. C. Nooy. 1981. Comparison of proteolysis in a low-fat semi-hard type of cheese manufactured by standard and by ultrafiltration techniques. Neth. Milk Dairy J. 35:35-46.

Emmons, D. B., and D. C. Beckett. 1990. Milk-clotting enzymes. 1. Proteolysis during cheese-making in relation to estimated losses of yield. J. Dairy Sci. 73:2007-2015.

Emmons, D. B., C. A. Ernstrom, C. Lacroix, and P. Verret. 1990. Predictive yield formulas for yield of cheese. J. Dairy Sci. 73:1365-1394.

Geurts, T. J. 1978. Some factors which affect the moisture content of cheese before salting. Neth. Milk Dairy J. 32:112-124.

Groen, A. F., R. van der Vegt, A. A. J. S. van Boekel, O. L. A. M. de Rouw, and H. Vos. 1994. Case study on individual animal variation in milk protein composition as estimated by high-pressure liquid chromatography. Neth. Milk Dairy J. 48:201-212.
International Dairy Federation. 1964. Determination of casein content of milk. Standard 29. IDF, Brussels.

International Dairy Federation. 1983. Determination of fat content (milk)_Röse-Gottlieb gravimetric method (reference method). Standard 1C. IDF, Brussels.

International Dairy Federation. 1985. Guidance on sampling. Standard 50B. IDF, Brussels.

International Dairy Federation. 1986a. Determination of fat content (cheese). Standard 5B. IDF, Brussels.

International Dairy Federation. 1986b. Determination of nitrogen content (Kjeldahl method) and calculation of crude protein content. Standard 20A. IDF, Brussels.

Karman, A. H., M. A. J. S. van Boekel, and A. P. Arentsen-Stasse. 1987. A simple and rapid method to determine the casein content of milk by infrared spectrophotometry. Neth. Milk Dairy J. 41:175-187.

Kumosinski, T. F., E. M. Brown, and H. M. Farrell Jr. 1991. Threedimensional molecular modeling of bovine caseins: $\alpha_{\mathrm{s} 1}$-casein. J. Dairy Sci. 74:2889-2895.

Lo, C. G., and E. D. Bastian. 1998. Incorporation of native and denatured whey proteins into cheese curd for manufacture of reduced fat, Havarti-type cheese. J. Dairy Sci. 81:16-24.

Lolkema. H. 1994. Cheese yield used as an instrument for process control-Experience in Friesland, the Netherlands. Chapt. 14 In Factors Affecting the Yield of Cheese. Special Issue No. 9301. International Dairy Federation, Square Vergote 41, B-1030, Brussels.

Modler, H. W., and D. B. Emmons. 1989a. Production and yield of whole-milk ricotta manufactured by a continuous process. I. Materials and methods. Milchwissenschaft 44:673-676.

Modler, H. W., and D. B. Emmons. 1989b. Production and yield of whole-milk ricotta manufactured by a continuous process. II. Results and discussion. Michwissenschaft 44:753-757.

Ng-Kwai-Hang, K. F., and J. P. Pelissier. 1989. Rapid separation of bovine caseins by mass ion exchange chromatography, J. Dairy Res. 56:391-397.

O'Keefe, A. M., P. F. Fox, and C. Daly. 1978. Proteolysis in Cheddar cheese: role of coagulant and starter bacteria. J. Dairy Res. 45:465-477.

Posthumus, G., C. J. Booy, and C. J. Klijn. 1964. The relation between the protein content of milk and cheese yield. Neth Milk Dairy J. 18:155-164.

Puhan, Z., and E. Jakob. 1994. Genetic variants of milk proteins and cheese yield. In Cheese Yield \& Factors Affecting Its Control, IDF Seminar, Cork, Ireland, 1993. Special Issue No. 9402. International Dairy Federation, Square Vergote 41, B-1030 Brussels.

Reinbold, R. S., and C. A. Ernstrom. 1988. Effect of nonuniform cooling on moisture, salt, and $\mathrm{pH}$ distribution in 290-kilogram blocks of stirred-curd Cheddar cheese. J. Dairy Sci. 71:14991506.

Rowland, S. J. 1938. The determination of the nitrogen distribution in milk. J. Dairy Res. 9:42-57.

Swaisgood, H. E. 1992. Chemistry of the caseins. In Advanced Dairy Chemistry-1: Proteins. Ed. by P. F. Fox. Elsevier Applied Sci., London.

van Boekel, M. A. J. S. 1994. Transfer of milk components to cheese: scientific considerations. In Cheese Yield \& Factors Affecting its Control, IDF Seminar, Cork, Ireland, 1993. Special Issue No. 9402. International Dairy Federation, Square Vergote 41, B1030 Brussels.

van Boekel, M. A. J. S., and C. L. Crijns. 1994. Behaviour of the proteose-peptone fraction during the renneting of milk. Neth. Milk Dairy J. 48:117-126.

van Boekel, M. A. J. S., and B. Ribadeau-Dumas. 1987. Addendum to the evaluation of the Kjeldahl factor for conversion of the nitrogen content of milk and milk products to protein content. Neth. Milk Dairy J. 41:281-284.

van Boekel, M. A. J. S., and P. Walstra. 1989. Steric exclusion of serum proteins with respect to (para)casein micelles. Neth. Milk Dairy J. 43:437-446. 
van den Berg, G., P. J. de Koning, J. T. M. Escher, and H. Bovenhuis. 1992. Genetic polymorphism of $\kappa$-casein and $\beta$-lactoglobulin in relation to milk composition and processing properties. Neth. Milk Dairy J. 46:145-168.

van den Berg, G., E. de Vries, and A. G. J. Arentzen. 1973. (Translation: Which sampling method should be used for the exact determination of the curd-fines content of first whey?). NIZO-nieuws 1973(7):825-828.

van den Berg, M. G., G. van den Berg, and M. A. J. S. van Boekel. 1996. Mass transfer processes involved in Gouda cheese manu- facture, in relation to casein and yield. Neth. Milk Dairy J. 50:501-540

Van Slyke, L. L., and W. V. Price. 1949. Cheese. Orange Judd Co. Inc. New York, NY.

Van Slyke, L. L., and C. A. Publow. 1910. The Science and Practice of Cheese-Making. Orange Judd Co. Inc. New York, NY.

Walstra, P., and R. Jenness. 1984. Dairy Chemistry and Physics. John Wiley \& Sons, New York.

Webb, B. H., and A. H. Johnson. 1965. Fundamentals of Dairy Chemistry. Pub. by AVI Publishing Co. Inc., Westport Conn., U.S.A. 